\title{
Development of novel polymorphic microsatellite markers in Siganus fuscescens
}

\author{
X.Q. Mao ${ }^{1,2}$, Z.B. Li ${ }^{1,2}$, Y.F. Ning ${ }^{1,2}$, J.B. Shangguan ${ }^{1,2}$, Y. Yuan ${ }^{1,2}$, \\ Y.S. Huang ${ }^{1,2}$ and B.B. Li $^{1,2}$ \\ ${ }^{1}$ Fisheries College, Jimei University, Xiamen, China \\ ${ }^{2}$ Fujian Provincial Key Laboratory of Marine Fishery Resources and \\ Eco-environment, Xiamen, China \\ Corresponding author: Z.B. Li \\ E-mail: lizhongbao@jmu.edu.cn
}

Genet. Mol. Res. 15 (3): gmr.15037515

Received August 25, 2015

Accepted November 25, 2015

Published July 29, 2016

DOI http://dx.doi.org/10.4238/gmr.15037515

Copyright $(C 2016$ The Authors. This is an open-access article distributed under the terms of the Creative Commons Attribution ShareAlike (CC BY-SA) 4.0 License.

ABSTRACT. Rabbitfish, Siganus fuscescens, is widely distributed in the Indo-Pacific regions and eastern Mediterranean. Its dwelling place includes reef flats, coral reef regions, and seagrass meadows in tropical area and reef areas or shallow waters in locations at high latitudes. In the present study, 10 new polymorphic microsatellite markers were screened from 30 wild $S$. fuscescens individuals, using a method of fast isolation protocol and amplified fragment length polymorphism of sequences containing repeats. The number of polymorphic alleles per locus was 3 to 5 with a mean of 4.3 , while the value of polymorphic information content ranged from 0.283 to 0.680 . The values of the observed and expected heterozygosities were in the range $0.3333-0.8462$ and 0.3011 0.7424 , respectively. Deviation from Hardy-Weinberg equilibrium was not observed in this study. These polymorphic loci are expected to be effective in evaluating the genetic diversity, population structure, and 
gene flow and in determining the paternity in S. fuscescens, as well as for conservation management.

Key words: Siganus fuscescens; Microsatellites; Genetic markers; FIASCO

\section{INTRODUCTION}

The mottled spinefoot, Siganus fuscescens, classified in the order Perciformes, family Siganidae (rabbitfishes), genus Siganus, is characterized by having three soft rays between their inner and outer spine, and seven anal fin spines. Its body is olive green or brown with a silver belly and small spots. The fish displays a mottled color and projects its venomous spines, when frightened. Therefore, it has different names, such as dusky or sandy spinefoot in the United States, dusky rabbitfish in Australia, and barangen in Philippines. S. fuscescens is widely distributed in the Indo-Pacific and eastern Mediterranean region, from Korea to Australia. The habitat of $S$. fuscescens, an omnivorous fish, ranges from reef flats, coral reef regions, and seagrass meadows in the tropical area to reef areas or shallow waters in high latitude regions. S. fuscescens is a species with high economic value. It is a popular mariculture species (Bryan and Madraisau, 1977) with a good taste, is a high protein fodder, and can be harvest throughout the year (Alcala, 1979). As a result, its production increased sharply, causing a situation of overfishing. To counter this urgent situation, appropriate measures are needed to protect and make sustainable development of S. fuscescens.

Microsatellite DNA or simple sequence repeats (SSRs) are tandem repeats ranging from 1 to 6 nucleotides, found at a high-frequency in the nuclear genomes. Different individuals exhibit variations in these, which are manifested as repeat number differences (Guichoux et al., 2011), high-mutation rates of SSRs (Selkoe and Toonen, 2006), and mutational mechanisms (Li et al., 2002) resulting in the appearance of length polymorphisms. Microsatellite DNA has an advantage over other morphological markers as it reveals co-dominantly inherited multiallelic products of the loci. Moreover, it is free from the consequences of epistasis and other issues because of environmental conditions. In the study of population genetics, population differentiation, and evolution, SSRs are considered to be effective tools for genetic conservation. In the present study, 10 microsatellite markers were screened to obtain information useful for population genetic studies and protection of species resources. Microsatellite markers have already been used as a genetic tool for population studies in S. fuscescens (Li et al., 2013; Ning et al., 2015).

\section{MATERIAL AND METHODS}

\section{Fish sample collection and DNA extraction}

Wild S. fuscescens (30 individuals) were captured in Xiamen, China and preserved in alcohol at $-20^{\circ} \mathrm{C}$. Genomic DNA was extracted from single individuals using the standard phenol-chloroform extraction method (Sambrook et al., 2000). Concentration of the extracted DNA was estimated by electrophoresis on a $1 \%$ agarose gel and detection using an ultraviolet spectrophotometer. The DNA sample was finally stored at $-20^{\circ} \mathrm{C}$.

Genetics and Molecular Research 15 (3): gmr.15037515 


\section{Microsatellite-enriched library construction}

Microsatellite-enriched library of S. fuscescens was constructed by the fast isolation by amplified fragment length polymorphism of sequences containing repeats (FIASCO) protocol (Zane et al., 2002). The DNA samples were digested with the restriction endonuclease FastDigest Tru $1 \mathrm{I}$ at $65^{\circ} \mathrm{C}$ for $10 \mathrm{~min}$. Blunt-ended fragments ranging from 500 to $1000 \mathrm{bp}$ were selected and ligated to $M s e$ I adapter A (5'-ACGATGAGTCCTGAG-3')/MseI adapter B (5'-TACTCAGGACTCAT-3') using T4 DNA ligase (Fermentas, Vilnius, Lithuania) at $37^{\circ} \mathrm{C}$ for $3.5 \mathrm{~h}$. The product was denatured at $95^{\circ} \mathrm{C}$ for $10 \mathrm{~min}$ and enriched for microsatellite repeats by hybridization to the biotin-labeled oligonucleotide probes $(\mathrm{CT})_{15}$ and $(\mathrm{GT})_{15}$ at $61^{\circ} \mathrm{C}$ for $1 \mathrm{~h}$. The linker-ligated fragments were captured via streptavidin-coated magnetic beads (Promega, Madison, WI, USA). Enriched single stranded repeats were amplified by polymerase chain reaction (PCR) using MseI adapter A. Subsequently, the isolated fragments with potential SSRs were ligated into PMD19-T vector (Takara, Shiga, Japan) at $16^{\circ} \mathrm{C}$ for $3.5 \mathrm{~h}$ and transformed into One Shot chemically competent Escherichia coli DH5a cells (Tiangen, Beijing, China). The cells were then plated on Luria-Bertani agar plates containing $60 \mathrm{mg} / \mathrm{mL}$ ampicillin and grown overnight at $37^{\circ} \mathrm{C}$. The recombinant clones were detected by PCR amplification using universal M13 primers and the PCR products were visualized on 1\% agarose gels. A total of 150 positive clones with fragments ranging from 400 to $1000 \mathrm{bp}$ were chosen, for further sequencing by Life Technologies (Carlsbad, CA, USA).

\section{Primer design and polymorphism test}

A total of 107 positive clones containing the SSRs were obtained by using the software SSRhunter1.3 ( $\mathrm{Li}$ and Wan, 2005); these clones were sufficient to provide for the needs of the present study. Meanwhile, 68 pairs of microsatellite amplification primers were designed through the Primer Premier version 5.0 software (Clarke and Gorley, 2001). To test for polymorphism, 30 genomic DNA samples, extracted earlier from the 30 wild $S$. fuscescens individuals, were used for optimizing the amplification conditions for each primer pair; 33 primer pairs were successfully selected for testing by amplification of genomic DNA. Subsequently, individual loci were amplified in $10-\mu \mathrm{L}$ reactions containing $50 \mathrm{ng} / \mathrm{mL}$ genomic DNA templates, $10 \mathrm{X}$ Taq buffer, $0.4 \mathrm{M}$ each primer, $0.2 \mathrm{mM}$ each dNTPs, and $0.25 \mathrm{U}$ Taq DNA polymerase (Fermentas). Cycling parameters were set as follows: denaturation at $94^{\circ} \mathrm{C}$ for $5 \mathrm{~min}$, followed by 30 cycles at $94^{\circ} \mathrm{C}$ for $40 \mathrm{~s}$, a primer-specific annealing temperature (Table 1) for $40 \mathrm{~s}$, and extension at $72^{\circ} \mathrm{C}$ for $60 \mathrm{~s}$. This was followed by a final extension at $72^{\circ} \mathrm{C}$ for $10 \mathrm{~min}$. The PCR products were electrophoresed on $6 \%$ denaturing polyacrylamide gels using a Sequi-Gen Sequencing Cell system (Bio-Rad, Hercules, CA, USA) and visualized through silver staining.

\section{Data analysis}

Allele size were scored according to the 10-bp DNA ladder (Fermentas), while estimation of allelic diversity, tests for zygotic equilibrium (Hardy-Weinberg), and linkage disequilibrium (LD) as well as the observed and expected heterozygosities were conducted using POPGEN 32 (version 1.32; Yeh et al., 2000). Furthermore, CERVUS 3.0 (version 3.0) was used to calculate the polymorphic information.

Genetics and Molecular Research 15 (3): gmr.15037515 
X.Q. Mao et al.

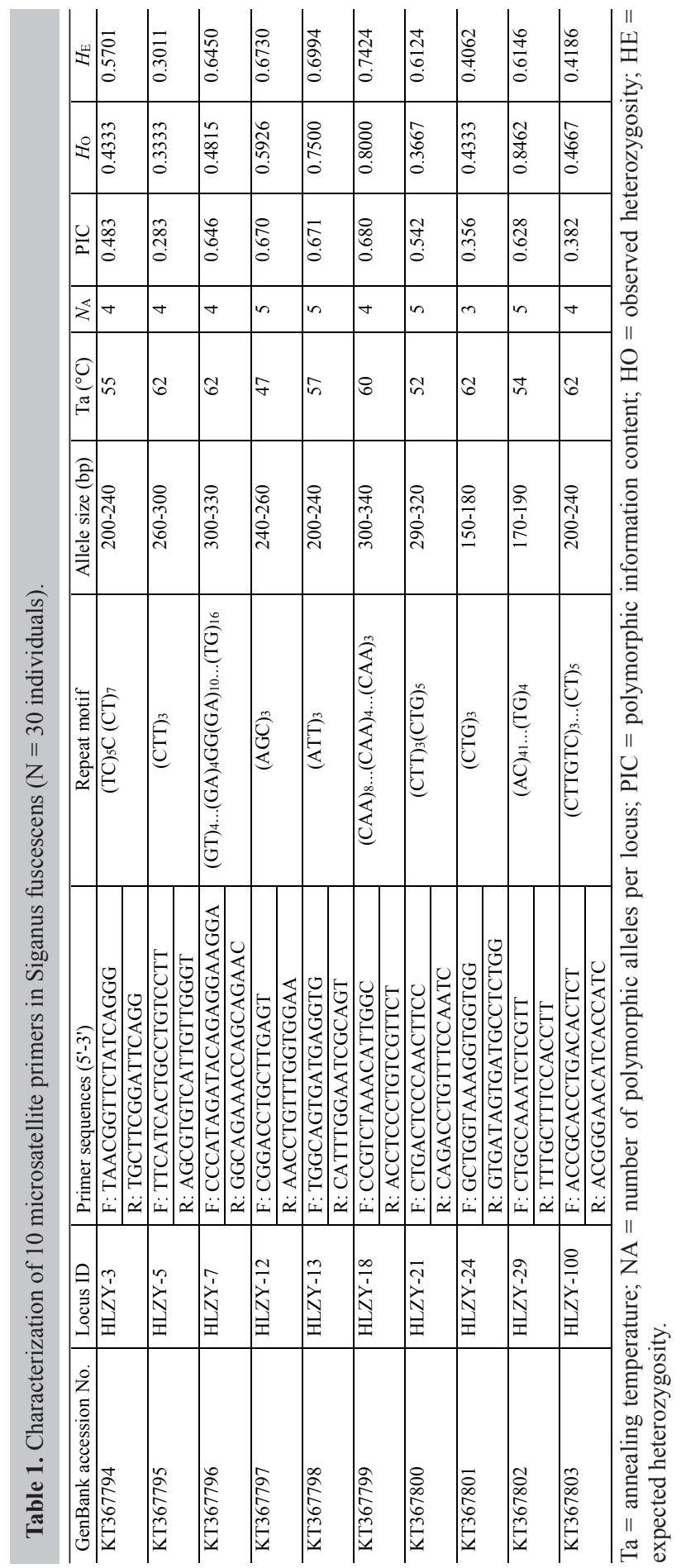

Genetics and Molecular Research 15 (3): gmr.15037515 


\section{RESULTS AND DISCUSSION}

Characterizations of the 10 polymorphic loci are shown in Table 1. Error analysis was carried out using MICRO-CHECKER (Van et al., 2004). None of the locus exhibited significant departure from the Hardy-Weinberg expectations $(\mathrm{P}>0.005)$. The number of polymorphic alleles per locus was $3-5$, with a mean of 4.3 . The value of polymorphic information content (PIC) ranged from 0.283 to 0.680 , which is commonly used in genetics as a measure of polymorphism for a marker locus used in linkage analysis. Four microsatellite loci appeared to be intermediately polymorphic $(0.25<\mathrm{PIC}<0.5)$ and the rest were considered to be highly polymorphic (PIC $>0.5$; Botstein et al., 1980). The values of the observed heterozygosities $\left(H_{\mathrm{O}}\right)$ were from 0.3333 to 0.8462 , with an average 0.5504 , whereas the range of the expected heterozygosities $\left(H_{\mathrm{E}}\right)$ was from 0.3011 to 0.7424 , with an average of 0.5683 .

\section{DISCUSSION}

Among the 107 positive clones, more than $90 \%$ were dinucleotide repeats, especially $(\mathrm{CT})_{\mathrm{n}}$, although $(\mathrm{GT})_{\mathrm{n}}$ had an advantage in terms of the number of repeats, which ranged from 4 to 84 . Moreover, $71.3 \%$ positive clones contained the SSRs, $66 \%$ could be designed for microsatellite amplification primers, and only 10 of the 68 pairs $(14.7 \%)$ could be amplified to polymorphic loci by PCR amplification, without the effects of null allele, stutter bands, short allele dominance, and allelic dropout, caused on genotyping of microsatellite. This demonstrates that enrichment was highly effective.

The value of $H_{\mathrm{O}}$ higher than $H_{\mathrm{E}}$ revealed the high genetic diversity of this population. All the 10 characteristics of the microsatellite loci indicated their potential utility in examining genetic diversity, variability, and demographic connectivity among the highly exploited $S$. fuscescens populations.

\section{Conflicts of interest}

The authors declare no conflict of interest.

\section{ACKNOWLEDGMENTS}

Research supported by the National Natural Science Foundation of China (\#31272668), the Program for New Century Excellent Talents in Fujian Province University, and the Foundation for Innovative Research Team of Jimei University, China (\#2010A004).

\section{REFERENCES}

Alcala AC (1979). Ecological notes on rabbitfishes (family Siganidae) and certain economically important marine animals in Southeastern Negros and environs, Philippines. Silliman J. 26: 115-133.

Botstein D, White RL, Skolnick M and Davis RW (1980). Construction of a genetic linkage map in man using restriction fragment length polymorphisms. Am. J. Hum. Genet. 32: 314-331.

Bryan PG and Madraisau BB (1977). Larval rearing and development of Siganus lineatus (Pisces: Siganidae) from hatching through metamorphosis. Aquaculture 10: 243-252. http://dx.doi.org/10.1016/0044-8486(77)90005-9

Clarke KR and Gorley RN (2001). PRIMER (Plymouth routines in multivariate ecological research) v5: user manual/ tutorial. Primer-E Ltd, Plymouth, 1-91.

Genetics and Molecular Research 15 (3): gmr.15037515 
Guichoux E, Lagache L, Wagner S, Chaumeil P, et al. (2011). Current trends in microsatellite genotyping. Mol. Ecol. Resour. 11: 591-611.http://dx.doi.org/10.1111/j.1755-0998.2011.03014.x

Li Q and Wan JM (2005). [SSRHunter: development of a local searching software for SSR sites]. Yi Chuan 27: 808-810.

Li QH, Li ZB, Dai G, Chen XJ, et al. (2013). Characterization of new microsatellite markers of Siganus fuscescens (Siganidae). Genet. Mol. Res. 12: 2751-2754.http://dx.doi.org/10.4238/2013.July.30.12

Li YC, Korol AB, Fahima T, Beiles A, et al. (2002). Microsatellites: genomic distribution, putative functions and mutational mechanisms: a review. Mol. Ecol. 11: 2453-2465.http://dx.doi.org/10.1046/j.1365-294X.2002.01643.x

Ning YF, Li ZB, Li QH, Dai G, et al. (2015). Isolation and characterization of novel microsatellite markers for molecular genetic diversity in Siganus fuscescens. Genet. Mol. Res. 14: 89-92. http://dx.doi.org/10.4238/2015.January.15.11

Sambrook JD, Russell W and Sambrook J (2000). Molecular Cloning. 2nd edn. Cold Spring Harbor Laboratory Press, Cold Spring Harbor, New York.

Selkoe KA and Toonen RJ (2006). Microsatellites for ecologists: a practical guide to using and evaluating microsatellite markers. Ecol. Lett. 9: 615-629. http://dx.doi.org/10.1111/j.1461-0248.2006.00889.x

Van OC, Hutchinson WF, Shipley P and Wills DPM (2004). MICRO-CHECKER: software for identifying and correcting genotyping errors in microsatellite data. Mol. Ecol. 4: 535-538. http://dx.doi.org/10.1111/j.1471-8286.2004.00684.x

Yeh FC, Yang R, Boyle TJ, Ye Z, et al. (2000). PopGene32, Microsoft Windows-based freeware for population genetic analysis. Version 1.32. Molecular Biology and Biotechnology Centre, University of Alberta, Alberta.

Zane L, Bargelloni L and Patarnello T (2002). Strategies for microsatellite isolation: a review. Mol. Ecol. 11: 1-16. http:// dx.doi.org/10.1046/j.0962-1083.2001.01418.x

Genetics and Molecular Research 15 (3): gmr.15037515 